УДК 342.9

DOI https://doi.org/10.32849/2663-5313/2020.3.22

Радислав Дутка,

аспірант кафедри адміністративного, фінансового та інформаційного права

Київського начіонального торговельно-економічного університету

\title{
ЗАПОБІГАННЯ ТА ВРЕГУЛЮВАННЯ КОНФЛІКТУ ІНТЕРЕСІВ ЯК АДМІНІСТРАТИВНО-ПРАВОВИЙ ІНСТИТУТ
}

Стаття присвячена дослідженню нормативних та доктринальних підходів до визначення поняття конфлікту інтересів. У статті наводяться аргументи щодо необхідності розмежування понять «потениійний конфлікт інтересів» та «реальний конфлікт» інтересів з урахуванням наявної правозастосовної практики. Автором проведений аналіз доктринальних підходів до визначення поняття «потениійний конфлікт інтересів», «реальний конфлікт інтересів», їх співвідношення з приватним інтересом публічного службовия. Окремі аналізовані доктринальні підходи до визначення відповідних понять піддаються обгрунтованій критиці. Автор вважає, що наявне нормативне визначення конфлікту інтересів є багато в чому кращим за значну частину доктринальних підходів, що дозволяє доволі ефективно використовувати його на практиці. У статті робиться висновок, що словосполучення «конфлікт інтересів» не потребує окремої дефініиії без уточнення характеру тако$2 о$ конфлікту інтересів. Адекватне та ефективне у правозастосуванні визначення можна надати виключно термінам «реальний конфлікт інтересів» та «потениійний конфлікт інтересів», оскільки вони є занадто відмінними, щоб єдиною дефініцією охопити спектр їхнього правового регулювання, а головне - ефективно вказати на їх відмінності. У статті також розкриваються складові елементи конфлікту (реального чи потениійного), за наявності яких він може мати місие, а також сфера його виникнення. Йдеться про поняття приватного інтересу, службових чи представницьких повноважень, суперечності між приватним інтересом і службовими чи представницькими повноваженнями. У статті обгрунтовується доиільність нормативного закріплення якомога ширшого змісту поняття «приватний інтерес». За результатами дослідження автором робиться акцент на необхідності визначення негативного наслідку виникнення суперечності між приватним та публічним інтересом у разі розмежування понять «реальний конфлікт інтересів» та «потениійний конфлікт інтересів». Автором наводяться власні пропозииї щодо вдосконалення нормативної дефініиї «реальний конфлікт інтересів».

Ключові слова: конфлікт інтересів, корупція, антикорупційне законодавство, відповідальність, приватний інтерес.

Постановка проблеми. Конфлікт інтересу та форми і методи його врегулювання і запобігання йому є невід'ємними правовими інститутами будь-якої держави із розвиненою системою стримування та противаг. Концепція публічної служби, представницького мандату у європейських країнах є неповноцінною без механізмів урегулювання та запобігання конфлікту інтересів, недотримання вимог яких тягне за собою вкрай негативні наслідки для потенційного порушника. У цьому контексті вкрай актуальним постає питання дослідження поняття конфлікту інтересів та його генези.

Стан дослідження. Питання дослідження поняття врегулювання та запобігання конфлікту інтересів неодноразово порушувалось у численних працях Т. Бодун, Т. Василевської, А. Гайдука, П. Волянського, Д. Гудкова, І. Лопушинського О. Олешка, С. Рівчаченка та інших.
| Метою статті є систематизація доктринальних підходів до визначення поняття конфлікту інтересів, порівняння таких підходів із нормативним закріпленням відповідного поняття у вітчизняному законодавстві та формулювання власних пропозицій щодо визначення поняття «конфлікт інтересів» у контексті ефективного правозастосування.

Виклад основного матеріалу. Базову дефініцію поняття конфлікту інтересів надає Закон України «Про запобігання корупції». При цьому в самому законі одразу закладена і нормативна класифікація цього поняття на потенційний та реальний конфлікт інтересів:

Потенційний конфлікт інтересів - це наявність у особи приватного інтересу у сфері, в якій вона виконує свої службові чи представницькі повноваження, що може 
вплинути на об'єктивність чи неупередженість прийняття нею рішень або на вчинення чи невчинення дій під час виконання зазначених повноважень [1].

Реальний конфлікт інтересів - суперечність між приватним інтересом особи та їі службовими чи представницькими повноваженнями, що впливає на об'єктивність або неупередженість прийняття рішень або на вчинення чи невчинення дій під час виконання зазначених повноважень [1].

Виходячи з викладених дефініцій, можна виявити чітку залежність між вказаними поняттями: потенційний конфлікт інтересів визначає наявність приватного інтересу, що може вплинути на об'єктивність прийняття рішень, тоді як реальний конфлікт інтересу визначає сам факт впливу в тій чи іншій формі приватного інтересу на об'єктивність прийняття рішень. Очевидним $є$ те, що потенційний конфлікт інтересу передує реальному конфлікту інтересу та переростає у нього внаслідок відповідного юридичного факту, на основі якого і встановлюється реальний вплив приватного інтересу на об'єктивність чи неупередженість прийняття особою рішень або на вчинення чи невчинення дій під час виконання службових повноважень

Доктринальні підходи до визначення поняття конфлікту інтересів доволі схожі.

На думку П. Волянського, конфлікт інтересів - це ситуація, за якої особиста зацікавленість державного службовця може вплинути на об'єктивність виконання ним службових повноважень та функцій і за якої існує можливість виникнення протиріччя між особистою зацікавленістю державного службовця і законними інтересами громадян, організацій, суспільства, держави, що може спричинити нанесення шкоди цим законним інтересам громадян, організацій, суспільства [2].

Д. Гудков вважає, що конфлікт інтересів - це колізія між державними інтересами в межах певної посади та приватними інтересами особи, яка займає дану посаду, що виникає внаслідок порушення основних принципів публічної служби, порушення обмежень та заборон, пов'язаних із публічною службою, недобросовісне виконання службових обов'язків посадовою особою, зокрема недотримання при їх виконанні прав і законних інтересів громадян, організацій, суспільства та держави, недодержання діючого законодавства, неякісне соціальне забезпечення публічних службовців [3].

Т. Василевська, досліджуючи питання конфлікту інтересів, надає одразу три визначення цього поняття з урахуванням запропонованої нею класифікації. На іï думку, фактичний конфлікт інтересів визначається як конфлікт між суспільно-правовими обов'язками та приватними інтересами державної посадової особи, за якого її приватні інтереси (що випливають із положення посадової особи як приватної особи) здатні неправомірним чином вплинути на виконання нею офіційних обов'язків або функцій. У свою чергу, на думку дослідниці, потенційний конфлікт інтересів виникає в тих випадках, коли державна посадова особа має такі приватні інтереси, які можуть призвести до конфлікту інтересів, якщо цій посадовій особі належить виконувати відповідні (тобто конфліктуючі з приватними інтересами) офіційні обов'язки в майбутньому [4, с. 109-111].

На думку Т. Бодун, конфлікт інтересів - це конфлікт між публічно-правовими обов'язками та приватними інтересами посадової особи, в якому службовець має свої особисті інтереси, що може негативно вплинути на виконання покладених на нього обов'язків та функцій [5].

Конфліктом інтересів, з погляду Н. Янюк, слід вважати ситуацію, за якої особиста заінтересованість публічного службовця може вплинути на об́'єктивність виконання ним службових повноважень, за якої існує можливість виникнення протиріччя між особистим інтересом публічного службовця і публічними, що може поставити під сумнів справедливість прийнятого рішення чи вчинення публічним службовцем інших дій [6].

О. Олешко у статті «Особливості управління конфліктом інтересів у сфері державної служби» трактує конфлікт інтересів як конфлікт між громадським обов'язком і приватними інтересами державного службовця, у якому державний службовець перебуває під впливом приватних інтересів, здатних відобразитися на виконанні ним своїх робочих обов'язків [7].

А. Гайдук стверджує, що конфлікт інтересів виникає в ситуації, коли посадовець має приватні інтереси, які можуть впливати або видаються такими, що впливають на неупереджене й об'єктивне виконання ним службових обов'язків [8, с. 102].

Аналізуючи наведені визначення, слід критично оцінювати підходи, в яких дослідники не розмежовують потенційний і реальний конфлікти інтересів. До прикладу, цитований вище О. Олешко стверджує, що конфліктом інтересів є ситуація, коли державний службовець перебуває під впливом приватних інтересів, які здатні відобразитись на виконанні ним робочих обов'язків. Така дефініція, на нашу думку, є невдалою з двох причин. 
По-перше, у ній відсутній акцент на моменті виникнення суперечності в доконаному стані, що впливає на упередженість чи об'єктивність прийняття рішень. Мова якраз про те розмежування - потенційний та реальний конфлікт інтересів. Дефініція, запропонована О. Олешком, розкриває суть якраз потенційного конфлікту інтересів. Однак подібну ситуацію не можна називати конфліктом інтересів без відповідного доповнення «потенційний», оскільки вона не обов'язково зумовлює виникнення власне конфлікту. Адже наявність приватного інтересу, який фактично не вплинув на об'єктивність прийняття державним службовцем рішення, не породжує суперечності приватного та публічного інтересу, яка лежить в основі досліджуваного інституту. Ось чому критично важливо відображати в дефініціях розмежування реального (очевидного, фактичного тощо) конфлікту інтересів, який за своєю суттю і є конфліктом, та потенційного конфлікту інтересів, який за своєю суттю не є конфліктом, однак лише в перспективі створює для його появи передумови.

По-друге, вказана дефініція жодним чином не коментує поняття наслідку виникнення суперечності між приватним та публічним інтересами. На нашу думку, такий наслідок повинен існувати, а його оцінка має бути негативною.

Окремо хочемо розібрати дефініцію конфлікту інтересів, запропоновану ще в 2013 році, до прийняття профільного закону. Ї̈і автором є О. Токар-Остапенко, яка стверджує, що очевидний конфлікт інтересів стосується ситуації, коли існує особистий інтерес, який може обгрунтовано вважатися іншими таким, що впливає на виконання державною посадовою особою своїх обов'язків, навіть якщо фактично негативного впливу немає (або не може бути). Потенційний конфлікт інтересів може бути в тих випадках, коли посадова особа має особисті інтереси, здатні призвести до конфлікту інтересів у певний час у майбутньому [9, с. 8].

Власне, запропоноване визначення очевидного (реального) конфлікту інтересів вважаємо таким, що не відповідає правовій суті відповідного інституту на сучасному етапі.

Дослідниця прямо пропонує відкинути вищеописаний наслідок реального конфлікту інтересів у формі впливу приватного інтересу на об'єктивність прийняття рішень, звузивши його до існування особистого інтересу, який може обгрунтовано вважатися іншими таким, що впливає на виконання державною посадовою особою своїх обо- в'язків, навіть якщо фактично негативного впливу немає. Власне, за умов відсутності доконаного факту негативного впливу конфлікту інтересів на об'єктивність прийняття державним службовцем рішень відсутні і негативні для держави наслідки.

Загалом, аналізуючи доктринальні підходи до визначення поняття «конфлікт інтересів», ми дотримуємося думки, що саме словосполучення «конфлікт інтересів» не потребує окремої дефініції без уточнення характеру такого конфлікту інтересів. Адекватне та ефективне у правозастосуванні визначення можна надати виключно термінам «реальний конфлікт інтересів» та «потенційний конфлікт інтересів», оскільки вони є занадто відмінними, щоб єдиною дефініцією охопити спектр їхнього правового регулювання, а головне - ефективно вказати на ї відмінності.

Аналіз нормативних та доктринальних дефініцій конфлікту інтересів дає можливість розкрити складові елементи конфлікту (реального чи потенційного), за наявності яких він може мати місце, а також сферу його виникнення. Ними є:

1) приватний інтерес;

2) службові чи представницькі повноваження;

3) суперечність між приватним інтересом і службовими чи представницькими повноваженнями.

Визначення приватного інтересу наведене в профільному законі: це будь-який майновий чи немайновий інтерес особи, у тому числі зумовлений особистими, сімейними, дружніми чи іншими позаслужбовими стосунками з фізичними чи юридичними особами, у тому числі ті, що виникають у зв'язку з членством або діяльністю в громадських, політичних, релігійних чи інших організаціях [1].

Таке визначення зумисно сформульоване законодавцем максимально широко. Виходячи з нього, будь-який зв'язок особи 3 іншою особою по суті буде породжувати виникнення приватного інтересу.

Вважаємо такий підхід виправданим. Саме по собі існування приватного інтересу не є проблемою. Більше того, в кожної людини існує сотні, тисячі найрізноманітніших приватних інтересів, що $є$, зрештою, природньо. Проблемою такий приватний інтерес стає лише тоді, коли він входить у протиріччя з публічним інтересом через службові обов'язки конкретної особи. Саме завдяки наведеній формулі широке тлумачення поняття «приватний інтерес» звужується до рамок, в межах яких воно може одержати ефективне правозастосування. 
Другим елементом дефініції є службові повноваження особи. Зміст та межі службових повноважень у юридичній літературі визначаються по-різному. Саме поняття «службові повноваження» на законодавчому рівні не закріплене. Зміст його розкривається через поняття службових злочинів, викладене у Кримінальному кодексі України: зловживання владою або службовим становищем; перевищення влади або службових повноважень працівником правоохоронного органу (ст. ст. 364-365 Кримінального кодексу України) тощо, які переважно вчиняються службовими особами. Такими визнаються особи, які постійно, тимчасово чи за спеціальним повноваженням здійснюють функції представників влади чи місцевого самоврядування, а також обіймають постійно чи тимчасово в органах державної влади, органах місцевого самоврядування, на державних чи комунальних підприємствах, в установах чи організаціях посади, пов'язані 3 виконанням організаційно-розпорядчих чи адміністративно-господарських функцій, або виконують такі функції за спеціальним повноваженням, яким особа наділяється повноважним органом державної влади, органом місцевого самоврядування, центральним органом державного управління зі спеціальним статусом, повноважним органом чи повноважною особою підприємства, установи, організації, судом або законом [10].

Питання конфлікту інтересів в аспекті службових повноважень стоїть особливо гостро у випадках, коли прийняття рішень державним службовцем зумовлюється здебільшого суб'єктивним критерієм. Практика показує, що більшість випадків, пов'язаних із виникненням конфлікту інтересів на державній службі, характеризуються якраз суб'єктивізмом у прийнятті рішень та зловживанням дискреційним підходом в управлінській діяльності.

Так, розробка державними органами чітких посадових інструкцій, законодавче оформлення службових повноважень конкретних посад сприятиме більш чіткому розумінню суті службових повноважень та унеможливить виникнення ситуацій, пов'язаних із вчиненням дій в умовах реального конфлікту інтересів.

Слід наголосити на вкрай раціональному зазначенні у законодавчому визначенні поняття конфлікту інтересів поняття «представницькі повноваження».

На думку I. Пастуха, перелік представницьких повноважень міститься, як правило, у відповідних законах, що визначають правовий статус відповідних органів та наділених ними осіб. Так, представницький орган місцевого самоврядування - виборний орган (рада), який складається з депутатів і відповідно до закону наділяється правом представляти інтереси територіальної громади і приймати від її імені рішення. Представницькі повноваження можуть мати й інші суб'єкти владних повноважень. Таким чином, представницькі повноваження надають можливість відповідним суб'єктам відповідно до закону від власного імені та/або за дорученням уповноважених суб'єктів (наприклад, територіальної громади, суб'єкта владних повноважень) вирішувати певне коло проблем і діяти в інтересах таких осіб [11, с. 141].

3 таким підходом можна погодитись. Справді, за своїм змістом представницькі повноваження значно відрізняються від службових повноважень. Водночас відповідний рубіж у контексті інституту врегулювання та запобігання конфлікту інтересів не має істотного значення в контексті свого правозастосування - можна констатувати, що порушення вимог щодо врегулювання та запобігання конфлікту інтересів однаково небезпечне для правовідносин, незалежно від того, чи таке діяння вчинене службовою особою чи особою, в якої наявний представницький мандат.

Третім елементом конфлікту інтересу $\epsilon$ суперечність між приватним інтересом і службовими чи представницькими повноваженнями.

Слід зауважити, що існування суперечності між приватним та публічним інтересом у діях державного службовця є спільним як для потенційного, так і для реального конфлікту інтересів.

Різниця у вказаних поняттях простежується крізь призму висвітлення наслідку існування такої суперечності. За умови, якщо суперечність впливає на об'єктивність прийняття рішень державним службовцем, йдеться про негативний наслідок, а відповідно, реальний конфлікт інтересів. За умови відсутності такої суперечності відсутній і негативний наслідок. Саме тому у вказаному випадку йдеться про потенційний конфлікт інтересів.

Ось чому за умови висвітлення загального поняття «конфлікт» інтересів науковці ведуть мову про три його складові елементи. Втім, як відомо, відповідальність за порушення вимог щодо врегулювання та запобігання конфлікту інтересів настає виключно у разі існування реального конфлікту інтересів. 3 огляду на викладене, правозастосовна діяльність у сфері конфлікту інтересів вимагає чіткого формулювання наслідку існування суперечності приватного та публічного інтересу. 
Формою такого наслідку виступає законодавче формулювання «що впливає на об'єктивність або неупередженість прийняття рішень або на вчинення чи невчинення дій під час виконання службових повноважень». На нашу думку, таке формулювання є доволі широким, що створює проблеми у його правозастосуванні.

Виходячи із вищевикладеної логіки, вважаємо за необхідне запропонувати власне бачення визначення реального конфлікту інтересів. При цьому зауважуємо, що закріплене в Законі України «Про запобігання корупції» визначення конфлікту інтересів відповідає духу цього правового інституту, детермінації реального конфлікту інтересів.

На нашу думку, реальний конфлікт інтересів є ситуацією, за якої приватний інтерес особи зумовлює вплив на об'єктивність чи неупередженість вчинення дій під час виконання особою своїх службових чи представницьких повноважень та породжуе у будь-якій формі негативні наслідки для суб'єктів управлінських правовідносин.

Слід зауважити, що такий вплив повинен бути матеріалізований у конкретних діях, рішеннях тощо. Предметом доказування у правозастосовній діяльності повинна бути форма такого впливу, а також сам наслідок.

\section{Висновки}

Поняття конфлікту інтересів доволі чітко відображене у законодавстві та відповідає основним критеріям, необхідним для його належного визначення. Нормативне відображення поняття «конфлікт інтересів» відображає базову класифікацію цього терміна на реальний та потенційний, а також включає в себе доктринальні підходи щодо визначення ключових елементів цих термінів у їх дефініції. Нормативне визначення конфлікту інтересів можна вважати якісно кращим за значну частину доктринальних підходів, що дозволяє ефективно використовувати його на практиці.

Водночас, окремі практичні аспекти застосування терміна «реальний конфлікт інтересів» зумовлюють необхідність закладення у його визначення концепції існування негативного наслідку як результату існування суперечності між приватним та публічним інтересом у діяльності державоднак потребує дрібного уточнення в частині

ного службовця. Такий наслідок не повинен мати якусь конкретно виражену форму, на кшталт шкоди, водночас ключовим для його визначення повинен бути його негативний характер.

\section{Список використаних джерел:}

1. Про запобігання корупції : Закон України від 14.10.2014. Відомості Верховної Ради. 2014. № 49. Ст. 2056 .

2. Волянський П. Б. Шляхи запобігання конфлікту інтересів на державній службі. Державне управління: удосконалення та розвиток : електронне наукове фахове видання. 2014. № 6. URL: http://www.dy.nayka.com.ua/ ?op $=1 \& z=726$ (дата звернення: 02.02.2020).

3. Гудков Д. В. Конфлікт інтересів та шляхи його врегулювання в національному законодавстві. Право і суспільство. 2014. № 1-2. С. 120-124.

4. Василевська Т. Е. Конфлікт інтересів на державній службі: етичні аспекти. Науковоінформамійний вісник Академії начіональної безпеки. 2014. № 1. C. 106-120. URL: http:// nbuv.gov.ua/UJRN/nivanb_2014_1_9 (дата звернення: 02.02.2020)

5. Бодун Т. Конфлікт інтересів як детермінанта реформування системи влади в Україні. 3бірник наукових праиь НАДУ / за заг. ред. В. П. Приходька. Київ : НАДУ, 2009. Вип. 2. С. 224-235.

6. Янюк Н. Конфлікт інтересів як причина корупції на публічній службі: правові засоби запобігання і протидії / Головне управління Держземагенства у Донецькій області. URL: http:/ donoblzem.gov.ua/bibliot/Korupcia/Yanyuk\%20 Konflikt\%20interesiv.htm. (дата звернення: 02.02.2020)

7. Олешко О. Особливості управління конфліктом інтересів у сфері державної служби. Державне управління та місиеве самоврядування. 2015. Вип. 1 (24). С. 254-265.

8. Гайдук А. В. Запобігання конфлікту інтересів на публічній службі: проблеми законодавчого врегулювання. Вісник академії адвокатури України. 2013. № 1. С. 101-107.

9. Токар-Остапенко О. В. Урегулювання конфлікту інтересів на державній службі: можливості застосування європейського досвіду в Україні : аналіт. доп. Київ : НІСД, 2013. 48 с.

10. Кримінальний кодекс України від 05.04.2001. Відомості Верховної Ради Украйни. 2001. № 25-26. Ст. 131.

11. Пастух І. Д. Межі службових та представницьких повноважень у конфлікті інтересів. Підприємниитво, господарство $i$ право. 2018. № 10. C. $140-145$.

The article is devoted to the research of normative and doctrinal approaches to defining of the notion of conflict of interests, which is widey used in Ukrainian law enforcement practice since 2014. The authormakes arguments on the necessity of differentiation of notions "potential conflict of interests" and "real conflict of interests" considering the existing law enforcement practice. The author provides the analysis of doctrinal approaches towards defining of notions "potential conflict of interests" and "real conflict of interests", correlation of these notions with the private interest of public of ficial. Some of analyzed doctrinal approaches 
are criticized by the author. The author considers the current normative definition of conflict of interests to be much better in comparison to a large amount of doctrinal approaches in terms of law enforcement practice. The conclusion is made that conflict of interests as a notion doesn't need a separate definition without specification of the character of such conflict. Effective law enforcement requires the terms "potential conflict of interests" and "real conflict of interests", which are too much different, so that there is a need to emphasize the difference between them in the normative definitions. It is also opened out the elements of conflict of interests (both real and potential), and the sphere of its occurrence. Such elements are private interest, public or representative powers and the contradiction between the private interest and public or representative powers. It is also justified the feasibility of the wide content of the notion "private interest" to be normatively fixed. As a result of the research the author makes an accent on the necessity of defining the negative consequence of existing the contradiction between the private and the public interest while differentiating the notions "potential conflict of interests" and "real conflict of interests". The author suggests his own propositions on the optimization of normative definition "real conflict of interests".

Key words: conflict of interests, corruption, anticorruption legislation, liability, private interest. 